\title{
Mass deacidification cost comparisons
}

\author{
By Richard D. Smith \\ President, Wei T'o Associates \\ Matteson, Illinois
}

The purpose of this report is to point out the costs of deacidifying a book in the Library of Congress mass deacidification system at its start up and full production output rates, in the Wei $\mathrm{T}^{\text {" }} \mathrm{o}^{\circledR}$ "pilot plant" Nonaqueous Book Deacidification System operating at the Public Archives of Canada as well as the full scale Wei T'o plant planned for future installation, and in the manual spray deacidification system developed at Princeton University Libraries using Wei T'o solutions (see Table 1).

The operational costs are selected from the following sources which can be independently confirmed. The LC operational costs were published in House Report No. 98-938. ${ }^{1}$ The Wei T'o pilot plant costs come from data provided by the Public Archives. ${ }^{2}$ The future full scale Wei T'o plant costs are predicted based on four years of operational experience in the pilot plant. The Princeton manual spray deacidification system costs are based on data provided by Princeton University Libraries. ${ }^{3}$

The capital costs are based upon data from the same sources. The 30 -year analysis period was selected because LC estimates the useful life of its projected facility will be 30 years. ${ }^{4}$ The current

${ }^{1}$ U.S. House Comm. on Public Works and Transportation, Library of Congress Mass Deacidification Facility. 98th Cong., 2d Sess., Report No. 98-938 on House Bill H.R.5607, August 2, 1984.

Jan Pidek, Director, Records Conservation, Public Archives of Canada, personal communication.

${ }^{3}$ Robert A. Parliament, Preservation Librarian, Princeton University Libraries, personal communication. A description of the Princeton system is given in Robert A. Parliament, "Construction and Start-up of the Deacidification Unit at Princeton University Library," Book and Paper Group Annual 2(1983): 82-85, published by the American Institute for Conservation, Washington, D.C.

${ }^{4}$ Peter G. Sparks and Richard D. Smith, "Deacidification Dialogue," C\&RL News 46(1985):9-11.

long-term U.S. Treasury Bond interest rate of $11.5 \%$ is used to compute the capital cost of the LC, Wei T'o, and Princeton equipment. Loss of purchasing power is compensated for by using an $8 \%$ per year adjustment for inflation.

The procedure for computing the capital cost per book used the standard accounting formula: I $=(1+i) n-1$ where "I" represents the compound interest, " $\mathrm{i}$ " the annual interest rate, and " $\mathrm{n}$ " the number of years. For example, the capital cost per book in the LC System at start-up is computed as shown at the bottom of this page.

The "adjustment for inflation" of $\$ 7.71$ at $8 \%$ per year is computed similarly. The costs for the other systems presented in Table 1 are obtained using the same procedures.

In summary, the cost of deacidifying one book will be between $\$ 7.96$ and $\$ 15.85$ using the LC system, between $\$ 2.46$ and $\$ 5.07$ using the Wei T'o systems, and the cost of deacidifying one book is now $\$ 11.23$ in the manual Princeton system. Approximately three books can be deacidified in the Wei T'o system at the same cost as deacidifying one book in the LC system. The Princeton manual spray system should also be considered because it is $41 \%$ less expensive than the LC system at start-up and such a system can provide students with helpful employment in a university library setting. Many costs have been overlooked in this unsophisticated analysis, such as the change in operational or treatment costs which will take place over the next thirty years. However, the magnitude of the cost ratios appears to be reasonable because the operational costs will change in each system. On the other hand, the cost, which is not included in the formula, of obtaining and transporting books from the bookstacks to the various treatment facilities will vary greatly.

$$
\begin{aligned}
\text { Capital cost per book } & =\frac{(\text { Original equipment cost })(1+\text { compound interest })}{(\text { No. of books deacidified each year }) \text { (No. of years of operation) }} \\
& =\frac{(\$ 11,500,000)(1+\mathrm{I})}{(500,000)(30)} \\
& =\frac{(\$ 11,500,000)\left(1+(1+0.115)^{30}\right)}{15,000,000}
\end{aligned}
$$

Capital cost per book $=\$ 20.08$ 
TABLE 1

COMPARISON OF MASS DEACIDIFICATION COSTS

\begin{tabular}{|c|c|c|c|c|c|c|}
\hline \multirow[b]{2}{*}{$\begin{array}{l}\text { ITEM } \\
\text { NO. }\end{array}$} & \multirow[b]{2}{*}{ COST PER BOOK } & \multicolumn{2}{|c|}{ LIBRARY OF CONGRESS } & \multicolumn{2}{|c|}{ WEI T'O ${ }^{\circledR}$ IN CANADA } & \multirow{2}{*}{$\begin{array}{c}\text { PRINCETON } \\
\text { SPRAY } \\
\text { DEACIDIFICATION }\end{array}$} \\
\hline & & AT START UP & IN FULL PROD. & $\begin{array}{l}\text { PUBLIC ARCHIVES } \\
\text { PILOT PLANT }\end{array}$ & $\begin{array}{l}\text { FUTURE FULL } \\
\text { SCALE PLANT }\end{array}$ & \\
\hline 1 & $\begin{array}{c}\text { Operational } \\
\text { Cost }\end{array}$ & $\begin{array}{c}\$ 3.48 \\
500,000 \text { Books } / Y_{r}\end{array}$ & $\begin{array}{c}\$ 1.78 \\
1,000,000 \text { Books } / \mathrm{Yr} .\end{array}$ & $\begin{array}{c}\$ 3.47 \\
168,000 \text { Books } / \text { Yr. }\end{array}$ & $\begin{array}{c}\$ 1.89 \\
1,000,000 \text { Books } / \text { Yr. }\end{array}$ & $\begin{array}{c}\$ 10.14 \\
27,300 \text { Books } / Y_{\mathrm{r}} .\end{array}$ \\
\hline 2 & $\begin{array}{c}\text { Capital Cost Using } \\
\text { Compound Interest Rate } \\
\text { of } 11.5 \% \text { per Year } \\
\text { for } 30 \text { Years }\end{array}$ & $\begin{array}{l}\qquad 20.08 \\
\text { Eqpt. Cost } \$ 1,000,000\end{array}$ & $\begin{array}{l}\qquad 10.04 \\
\text { Eqpt. Cost } \$ 1,000,000\end{array}$ & $\begin{array}{c}2.60 \\
\text { All Development } \\
\text { and Eqpt. Cost } \$ 500,000\end{array}$ & $\begin{array}{c}0.87 \\
\text { Eqpt. Cost } \$ 1,000,000\end{array}$ & $\begin{array}{c}1.76^{*} \\
\text { Eqpt. Cost } \$ 55,000\end{array}$ \\
\hline 3 & $\begin{array}{l}\text { Adjustment for In- } \\
\text { flation at } 8 \% \text { per } \\
\text { Year for } 30 \text { Years }\end{array}$ & 7.71 & 3.86 & 1.00 & 0.30 & 0.68 \\
\hline 4 & $\begin{array}{l}\text { Capital Cost after } \\
\text { Adjusting for In- } \\
\text { flation (Item } 2-3 \text { ) }\end{array}$ & 12.37 & 6.18 & 1.60 & 0.57 & 1.08 \\
\hline 5 & $\begin{array}{l}\text { Cost of Deacid- } \\
\text { ification Treatment } \\
\quad(\text { Item } 1+4)\end{array}$ & $\$ 15.85$ & $\$ 7.96$ & $\$ 5.07$ & $\$ 2.46$ & $\$ 11.23$ \\
\hline
\end{tabular}

*Production of 27,300 books per year is based on five FTE students spraying seven hours per day five days per week. The LC and Wei T'o production rates are based on 24 hour per day seven day per week operation. 
The Association of College and Research Libraries is now soliciting applications for two fellowships made possible by the Institute for Scientific Information in Philadelphia. The first, the Samuel Lazerow Fellowship for Research in Acquisitions or Technical Services in an Academic or Research Library, honors a senior vice-president of ISI who made outstanding contributions to these fields. The fellowship of $\$ 1,000$ is to foster advances in acquisitions or technical services by providing a practicing librarian with funds for research, travel, or writing.

The second award, the ACRL Doctoral Dissertation Fellowship, provides an award of $\$ 1,000$ to a doctoral student working on a dissertation in the area of academic librarianship.

Applications for both awards should be made to Sandy Whiteley, Associate Executive Director, ACRL/ALA, 50 E. Huron St., Chicago, IL 60611, and are due by December 1, 1985. The winners of the awards will be announced at the ALA Annual Conference in New York in 1986.

To be eligible for the Lazerow Fellowship, a librarian must be working in acquisitions or technical services in an academic or research library. The Fellowship supports research in acquisitions or technical services, including the technical services and acquisitions aspects of library automation and library management. Research projects in collection development or the compilation of bibliographies will not be supported by this Fellowship.

Application proposals should be brief (five pages or less) and include the following:

1. Description of research, travel, or writing project;

2. Schedule for the project;

3. An estimate of expenses.

An up-to-date curriculum vitae should accompany the proposal.

Proposals for the Lazerow Fellowship will be judged on the following:

1. Potential significance of the project to acquisitions or technical service work;

2. Originality and creativity;

3. Clarity and completeness of the proposal;

4. Evidence of interest in scholarship, such as a previous publication record.

The winner of the 1983 Fellowship was Denise Bedford, formerly of Stanford University. The 1985 winner is Anna L. Highsmith, head of Copy Cataloging at Texas A\&M University, for a comparative study of the cataloging components of several automated library systems.

In order to be eligible for the ACRL Doctoral Dissertation Award, the applicant must meet the following qualifications:
1. Be an active doctoral student in the academic librarianship area in a degree-granting institution;

2. Have all course work completed;

3. Have had a dissertation proposal accepted by the institution.

The application should be brief (less than ten pages) and include the following:

1. Description of the research, including significance and methodology;

2. A schedule for completion;

3. Budget and budget justification for items for which support is sought (these must be items for which no other support is available);

4 . The name of the dissertation advisor and committee members;

5. A cover letter from the dissertation advisor endorsing the proposal.

An up-to-date curriculum vitae should accompany the proposal. Proposals will be judged on the following criteria:

1. Potential significance of the research to the field of academic librarianship;

2. Validity of the methodology and proposed method of analysis;

3. Originality and creativity;

4. Clarity and completeness of the proposal;

5 . Presentation of a convincing plan for completion in a reasonable amount of time;

6 . Evidence of a continuing interest in scholarship, such as a previous publication record.

Previous winners of the Doctoral Dissertation Fellowship were Stanton Biddle (1983) and Donald Gould (1984). This year's co-winners are Vicki L. Gregory, Rutgers University, for "State Coordination of Higher Education and Academic Libraries"; and Joanne R. Euster, University of California, Berkeley, for "The Leader Role in Influencing the Central Environment of Academic Libraries."

For further information on either of these two awards, contact Sandy Whiteley, ACRL/ALA, 50 E. Huron St., Chicago, IL 60611; (312) 9446780 .

\section{New statistics published}

A statistical study of 86 non-ARL university libraries in the United States and Canada will be published this month by ACRL. The survey is based on the same statistical form used by the Association of Research Libraries. ACRL University Library Statistics 1983-84 will be available for $\$ 12$ (ACRL members) or $\$ 15$ (nonmembers). Order from ACRL, 50 E. Huron St., Chicago, IL 60611. ISBN 0-8389-6892-9. 